\title{
Asosiasi Echinodermata pada Ekosistem Padang Lamun di Pantai Samuh, Nusa Dua, Bali
}

\author{
Wahyu Ilvita Vindia ${ }^{a *}$, Pande Gde Sasmita Julyantoro a, Endang Wulandari a \\ a Program Studi Manajemen Sumberdaya Perairan, Fakultas Kelautan dan Perikanan, Universitas Udayana, Bukit Jimbaran, Bali-Indonesia \\ * Penulis koresponden. Tel.: +62-8579-0561-823 \\ Alamat e-mail: ilvitawahyu@yahoo.co.id
}

Diterima (received) 6 Oktober 2017; disetujui (accepted) 20 Agustus 2018; tersedia secara online (available online) 22 Agustus 2018

\begin{abstract}
Seagrass beds and their associate biota are very important in maintaining the balance of coastal ecosystems. Samuh Beach is one of seagrass ecosystem area in Bali Island. One of the biota that exists in the seagrass ecosystem in Samuh Beach is Echinodermata. Since the limited information and the complex activities at Samuh Beach make research about associations of Echinodermata with seagrass, this research seems become important to be conducted. This study was aimed to determine the density of species, species composition, and distribution patterns of lamun and Echinodermata in the coastal waters of Samuh beach. Data analysis was performed by using density type, species composition, dispersion index of morisita and association. The average seagrass density of each station in Samuh coastal waters ranged from 156-246 stands/m2 and the highest density of Echinoderms is Diadema setosum in each station. The species composition of seagrass in Samuh beach comprises five species of seagrass namely: Enhalus acoroides, Halophila ovalis, Thalassodendron ciliatum, Cymodocea serrulata and Syringodium isoetifolium. The composition of Echinodermata species that found amounted to 13 species of Echinodermata namely: Diadema setosum, Amphiura sp., Archaster typicus, Asterias sp., Mespilia globulus, Tripneustes gratilla, Pseudoboletia maculata, Protoreaster nodusus, Ophiactis resillens, Ophiopteris antipodum, Centrostephanus rodgersii, Echinothrix and Echinothrix mathei. Based on the calculation of morisita, seagrass and Echinodermata Index in Samuh Beach was spread uniformly and clumped. The result of association analysis showed that there were positive association, negative association and association with no relation between seagrass and Echinodermata in Samuh Beach.
\end{abstract}

Keywords: association; coastal; Echinodermata; Samuh; seagrass

\begin{abstract}
Abstrak
Keberadaan padang lamun dan biota asosiasi sangat penting dalam menjaga keseimbangan ekosistem di perairan. Pantai Samuh merupakan salah satu perairan yang memiliki ekosistem padang lamun di Pulau Bali. Salah satu biota yang terdapat pada ekosistem padang lamun di Pantai Samuh adalah Echinodermata. Masih terbatasnya informasi dan aktivitas di Pantai Samuh yang kompleks menjadikan penelitian tentang asosiasi Echinodermata dengan padang lamun menjadikan penelitian ini penting untuk dilakukan. Penelitian ini bertujuan untuk mengetahui kepadatan jenis, komposisi jenis, serta pola sebaran lamun dan Echinodermata di perairan Pantai Samuh. Analisis data dilakukan dengan menghitung kepadatan jenis, komposisi jenis, Indeks Dispersi Morisita dan Indeks Asosiasi. Kepadatan lamun pada semua stasiun di perairan Pantai Samuh berkisar antara 156-246 tegakan/m2 dan Kepadatan Echinodermata tertinggi adalah Diadema setosum pada masing-masing stasiun. Komposisi jenis lamun di perairan Pantai Samuh terdiri dari 5 spesies lamun yaitu Enhalus acoroides, Halophila ovalis, Cymodocea serrulata, Thalassodendron ciliatum dan Syringodium isoetifolium. Komposisi jenis Echinodermata yang ditemukan pada penelitian ini berjumlah 13 spesies yaitu Diadema setosum, Amphiura sp., Archaster typicus, Asterias sp., Mespilia globulus, Tripneustes gratilla, Pseudoboletia maculata, Protoreaster nodusus, Ophiactis resillens, Ophiopteris antipodum, Centrostephanus rodgersii, Echinothrix dan Echinothrix mathei. Berdasarkan hasil perhitungan Indeks Dispersi Morisita, lamun dan Echinodermata di Pantai Samuh memiliki pola seragam dan mengelompok. Hasil analisis asosiasi menunjukkan bahwa terdapat asosiasi positif, asosiasi negative dan asosiasi tidak berhubungan antara lamun dengan Echinodermata di perairan Pantai Samuh.
\end{abstract}

Kata Kunci: asosiasi; Echinodermata; lamun; Pantai Samuh 


\section{Pendahuluan}

Pantai Samuh merupakan salah satu pantai yang terdapat di Bali yang bertempat di depan Hotel Melia Bali, Nusa Dua. Pantai Samuh memiliki spot ekowisata bahari bawah laut, tempat untuk pendaratan kapal nelayan, dan ekosistem terumbu karang. Pantai Samuh juga memiliki ekosistem padang lamun yang sangat luas dan masih bagus (Hidayanti, 2016).

Ekosistem padang lamun merupakan ekosistem yang memiliki keanekaragaman hayati dan memiliki produktivitas primer yang tinggi pada daerah laut dangkal, dan berasosiasi dengan berbagai kelompok organisme. Padang lamun yang dijumpai di alam sering berasosiasi dengan flora dan fauna akuatik lainnya, seperti algae, meiofauna, moluska, Echinodermata, krustasea, dan berbagai jenis ikan (Rasyid, 2001).

Salah satu biota yang ada pada ekosistem padang lamun di Pantai Samuh adalah Echinodermata. Echinodermata merupakan hewan yang memiliki duri dan memiliki kemampuan autotomi serta regenerasi bagian tubuh yang hilang, putus dan rusak. Keberadaan Echinodermata selain sebagai sumber makanan bagi hewan lain, juga berfungsi sebagai pemakan bangkai dan pemakan partikel-partikel yang membusuk di laut (Hadi et al., 2011).

Masih terbatasnya informasi penelitian tentang asosiasi Echinodermata dengan padang lamun, sehingga penelitian ini penting untuk dilakukan. Penelitian ini bertujuan untuk mengetahui kepadatan, komposisi spesies, sebaran dari Echinodermata dan padang lamun serta menganalisis asosiasi Echinodermata dengan padang lamun di Pantai Samuh, Nusa Dua, Bali.

\section{Metode Penelitian}

\subsection{Waktu dan Lokasi Penelitian}

Penelitian ini dilaksanakan pada Bulan JanuariFebruari 2017 yang dilakukan pada saat surut terendah. Pengambilan data dilakukan sebanyak 4 kali pada setiap stasiun. Penelitian ini terletak di Pantai Samuh, Kelurahan Tanjung Benoa, Kecamatan Nusa Dua, Kabupaten Badung, Bali (Gambar 1).

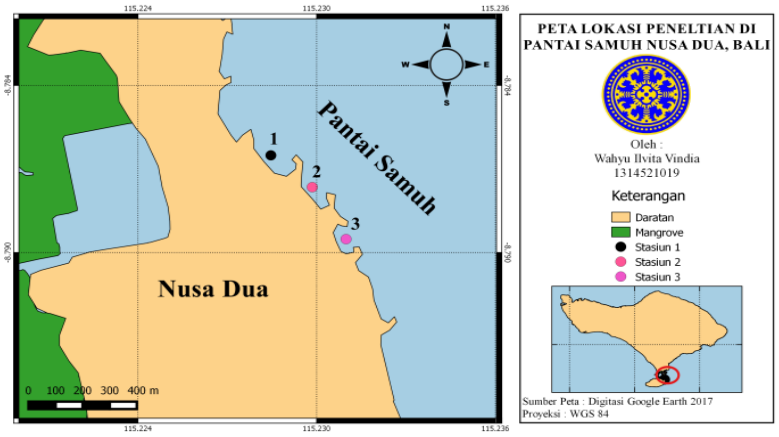

Gambar 1. Peta lokasi penelitian

\subsection{Alat dan Bahan}

Alat dan Bahan yang digunakan dalam penelitian disajikan dalam Tabel 1.

\section{Tabel 1}

Alat dan Bahan yang digunakan dalam penelitian

\begin{tabular}{|c|c|}
\hline Alat dan Bahan & Kegunaan \\
\hline Coolbox & Untuk menyimpan sampel \\
\hline DO meter & $\begin{array}{l}\text { Untuk mengukur kadar } \\
\text { oksigen terlarut }\end{array}$ \\
\hline $\mathrm{pH}$ meter & $\begin{array}{l}\text { Untuk mengukur derajat } \\
\text { keasaman }\end{array}$ \\
\hline Refraktometer & Untuk mengukur salinitas \\
\hline Transek kuadran & $\begin{array}{l}\text { Untuk pembatas area } \\
\text { pengambilan sampel }\end{array}$ \\
\hline GPS & $\begin{array}{l}\text { Untuk menentukan titik } \\
\text { koordinat }\end{array}$ \\
\hline $\begin{array}{l}\text { Garis transek (Line } \\
\text { transek) }\end{array}$ & $\begin{array}{l}\text { Untuk menarik garis antar } \\
\text { titik dalam satu stasiun }\end{array}$ \\
\hline Botol sampel & Untuk sampel kualitas air \\
\hline Camera & Untuk dokumentasi \\
\hline Formalin $4 \%$ & $\begin{array}{l}\text { Untuk mengawetkan sampel } \\
\text { Echinodermata }\end{array}$ \\
\hline $\begin{array}{l}\text { Sampel lamun dan } \\
\text { Echinodermata }\end{array}$ & $\begin{array}{l}\text { Untuk menganalisis asosiasi } \\
\text { antara Echinodermata dengan } \\
\text { lamun }\end{array}$ \\
\hline Aquades & Untuk mensterilkan alat \\
\hline
\end{tabular}

\subsection{Metode Pengambilan Data}

\subsubsection{Penentuan titik stasiun}

Metode yang digunakan dalam penentuan lokasi penelitian ini adalah metode purposive sampling. Terdapat 3 stasiun pengamatan yaitu Stasiun 1 merupakan tempat pendaratan kapal nelayan, Stasiun 2 merupakan area ekowisata bahari serta banyak aktivitas wisatawan, dan Stasiun 3 merupakan kawasan pantai yang dikelola hotel (Gambar 2). 


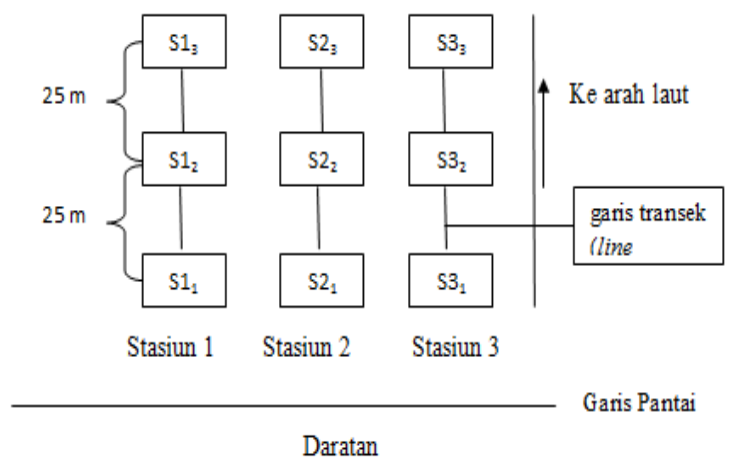

Gambar 2. Desain lokasi pengamatan stasiun

\subsubsection{Pengambilan sampel Echinodermata}

Pengambilan sampel Echinodermata dilakukan dengan menggunakan metode transek kuadran berukuran $1 \times 1 \mathrm{~m}$ yang dilakukan pada saat surut terendah. Pada setiap titik ditarik garis transek (line transek) tegak lurus dari garis pantai ke arah laut. Sampel Echinodermata diambil dan diawetkan menggunakan formalin $4 \%$, selanjutnya diidentifikasi di Laboratorium Ilmu Perikanan, Fakultas Kelautan dan Perikanan Universitas Udayana.

\subsubsection{Pengambilan sampel Lamun}

Pengambilan data lamun menggunakan transek kuadran berukuran $1 \times 1 \mathrm{~m}$ yang dilakukan pada saat surut terendah. Data lamun diambil sekali pada awal pengambilan data yang dilakukan pada setiap titik di semua stasiun yaitu jumlah tegakan dari setiap jenis. Sampel lamun yang diambil dan dimasukkan ke dalam kantong plastik yang telah diberi label sebagai penanda untuk identifikasi dan dokumentasi.

\subsubsection{Pengambilan Data Prameter Kualitas Air}

Pengukuran parameter fisika dan kimia perairan yang meliputi suhu, DO, $\mathrm{pH}$ dan salinitas dilakukan saat kondisi air surut terendah di setiap titik di Stasiun 1, Stasiun 2 dan Stasiun 3.

\subsection{Analisis Data}

\subsubsection{Kepadatan Jenis}

Kepadatan jenis (Di) adalah jumlah individu Echinodermata dan (tegakan) lamun per satuan luas. Kepadatan masing-masing jenis pada setiap stasiun dihitung dengan menggunakan rumus (Brower et al. 1989):

$$
D i=\frac{n i}{A}
$$

dimana Di adalah jumlah individu Echinodermata dan (tegakan) lamun ke-i per satuan luas; Ni adalah jumlah individu Echinodermata dan (tegakan) lamun ke -i dalam transek kuadrat; A adalah luas transek kuadrat.

\subsubsection{Komposisi Jenis}

Komposisi jenis atau kepadatan relatif jenis yaitu persentase jumlah individu suatu jenis terhadap jumlah individu secara keseluruhan. Komposisi jenis lamun dan Echinodermata dihitung dengan rumus (Brower et al. 1989):

$$
R D i=\frac{n i}{\sum_{i=1}^{p} N i j} x 100 \%
$$

dimana RDi adalah komposisi jenis ke-i (\%); Ni adalah jumlah individu (tegakan) ke-i dalam transek kuadran; $\sum_{i=1}^{p} N i j$ adalah jumlah total individu seluruh spesies.

\subsubsection{Pola Sebaran}

Pola sebaran spesies lamun dan Echinodermata ditentukan dengan menghitung Indeks Dispersi Morisita (Brower et al. 1989) dengan persamaan:

$$
I d=\frac{n\left(\sum_{i=1}^{s} x 2-N\right)}{N(N-1)}
$$

dimana Id adalah Indeks Dispesi Morisita; $\mathrm{n}$ adalah jumlah plot pengambilan contoh; $\mathrm{N}$ adalah jumlah individu dalam $\mathrm{n}$ plot; $\mathrm{X}$ adalah Jumlah individu pada setiap plot.

Pola dispersi lamun ditentukan dengan menggunakan kriteria sebagai berikut (Brower et al. 1989):

$$
\begin{aligned}
& \text { Id }<1 \text { : Pola dispersi seragam } \\
& \text { Id }=1 \text { : Pola dispersi acak } \\
& \text { Id }>1 \text { : Pola dispersi mengelompok }
\end{aligned}
$$

2.4.4. Asosiasi Echinodermata Berdasarkan Habitat Lamun

Menurut Bass et al. (2013), pengujian asosiasi antar 2 jenis/spesies didasarkan pada ada atau tidaknya 
spesies dalam suatu penarikan contoh. Hal ini dapat dilakukan dengan menggunakan Tabel Kontegensi $2 \times 2$.

Tabel 2

Tabel Kontigensi $2 \times 2$

\begin{tabular}{ccccc}
\hline & & \multicolumn{3}{c}{ Spesies B } \\
\hline & Ada & Tidak & Jumlah \\
& & Ada & \\
\hline \multirow{2}{*}{ Spesies } & Ada & A & $\mathrm{b}$ & $\mathrm{a}+\mathrm{b}$ \\
$\mathrm{A}$ & Tidak & $\mathrm{C}$ & $\mathrm{d}$ & $\mathrm{c}+\mathrm{d}$ \\
& Ada & & & \\
\hline & Jumlah & $\mathrm{a}+\mathrm{b}$ & $\mathrm{b}+\mathrm{d}$ & $\mathrm{N}=\mathrm{a}+\mathrm{b}+\mathrm{c}+\mathrm{d}$ \\
\hline
\end{tabular}

dimana a adalah jumlah contoh dimana terdapat kedua spesies; b adalah jumlah contoh dimana hanya terdapat spesies $\mathrm{A}$; $\mathrm{c}$ adalah jumlah contoh dimana hanya terdapat spesies $\mathrm{B}$; $\mathrm{d}$ adalah jumlah contoh dimana kedua spesies tidak terdapat; $\mathrm{N}$ adalah jumlah total contoh.

Selanjutnya untuk menentukan tipe asosiasi menggunakan rumus sebagai berikut Bass at al. (2013):

$$
E(a)=\frac{(a+b)(a+c)}{N}
$$

dimana $\mathrm{E}(\mathrm{a})$ adalah nilai harapan independen; a adalah jumlah contoh dimana terdapat kedua spesies; b adalah jumlah contoh dimana terdapat kedua spesies A; c adalah jumlah contoh dimana terdapat kedua spesies $\mathrm{B}$; $\mathrm{N}$ adalah jumlah total contoh.

Dari perhitungan tersebut, tipe asosiasi dapat ditentukan menjadi dua macam, yaitu (Bass at al., 2013):

1. Asosisasi positif, jika nilai observasi a $>E(a)$, atau kenyataan bahwa kedua spesies lebih sering muncul bersama daripada nilai harapan independen.

2. Asosiasi negatif, jika nilai observasi a $<E(a)$, atau kenyataan bahwa kedua spesies lebih sering tidak hadir bersama daripada nilai harapan independen.

3. Asosiasi tidak ada hubungan, asosiasi ini terjadi apabila nilai a = Ea nilai ini dijadikan sebagai penyeimbangan kekuatan positif dan negatif (Mayasari et al. (2012).

Menurut (Bass at al., 2013), untuk mengetahui tingkat asosiasi antar 2 jenis/spesies organisme dapat diukur dengan menghitung indeks asosiasi menggunakan rumus indeks Jaccard sebagai berikut:

$$
J I=\frac{a}{a+b+c}
$$

dimana JI adalah Indeks Jaccard; a adalah jumlah contoh dimana terdapat kedua spesies; $b$ adalah jumlah contoh dimana hanya terdapat spesies A; c adalah jumlah contoh dimana hanya terdapat spesies B.

Indeks Jaccard berada pada selang nilai $0-1$. Jika nilai Indeks Jaccard mendekati angka 1, maka hal tersebut menunjukan bahwa hubungan antara kedua spesies semakin kuat. Tabel 3 merupakan tingkat asosiasi berdasarkan pengelompokan indeks asosiasi.

Tabel 3

Kelas indeks asosiasi

\begin{tabular}{ccl}
\hline No. & $\begin{array}{c}\text { Indeks } \\
\text { Asosiasi }\end{array}$ & \multicolumn{1}{c}{ Keterangan } \\
\hline 1 & $1.00-0.75$ & Sangat Tinggi \\
2 & $0.74-0.49$ & Tinggi \\
3 & $0.48-0.23$ & Rendah \\
4 & $<0.22$ & Sangat Rendah \\
\hline
\end{tabular}

Sumber: Kurniawan et al., 2008

\section{Hasil dan Pembahasan}

\subsection{Kepadatan Jenis}

\subsubsection{Kepadatan Jenis Lamun}

Hasil kepadatan jenis lamun pada Stasiun 1 berkisar sekitar 2-77 (tegakan/m²), pada Stasiun 2 dengan kisaran 1-79 (tegakan/m²), sedangkan pada Stasiun 3 berkisar sekitar 5-93 (tegakan/m²) (Tabel 4). Kepadatan lamun tertinggi terdapat di Stasiun 3 yaitu sebanyak 246 tegakan $/ \mathrm{m}^{2}$. Kepadatan lamun yang diperoleh dari hasil pengukuran pada setiap stasiun relative sedikit jika dibandingkan dengan yang didapatkan oleh Laharjana (2016) yang melakukan penelitian Asosiasi Moluska Bentik dengan lamun di Perairan Pulau Serangan Bali dengan hasil kepadatan lamun tertinggi. sebanyak 783 tegakan/m2.

Kepadatan lamun tertinggi pada Stasiun 3 diduga karena adanya gundukan batuan karang sejauh $\pm 150 \mathrm{~m}$ dari tubir pantai. Gundukan batuan karang tersebut berfungsi sebagai pemecah gelombang, sehingga perairan di Stasiun 3 memiliki arus lemah dibandingkan dengan stasiun lainnya. Hal ini sesuai dengan pernyataan Dwindaru (2012), bahwa tingkat kelangsungan 
hidup lamun dipengaruhi oleh kondisi lingkungan seperti gelombang dan arus. Menurut (Riniatsih, 2016) lamun tidak tumbuh di pantai yang terjal dan berombak besar dengan arus pasang surut yang kuat.

Tabel 4

Kepadatan Jenis Lamun di Pantai Samuh

\begin{tabular}{|c|c|c|c|c|}
\hline \multirow[b]{2}{*}{ Nama Spesies } & \multicolumn{3}{|c|}{ Stasiun (tegakan/m²) } & \multirow{2}{*}{$\begin{array}{c}\text { Total } \\
\left(\begin{array}{c}\text { tgak } / \mathrm{m}^{2} \\
)\end{array}\right.\end{array}$} \\
\hline & $\begin{array}{c}\text { Stasiu } \\
\text { n } 1 \\
\end{array}$ & $\begin{array}{c}\text { Stasiu } \\
\mathrm{n} 2 \\
\end{array}$ & $\begin{array}{c}\text { Stasiu } \\
\text { n } 3 \\
\end{array}$ & \\
\hline $\begin{array}{l}\text { Enhalus } \\
\text { acoroides }\end{array}$ & 44 & 34 & 53 & 131 \\
\hline $\begin{array}{l}\text { Syringodium } \\
\text { isoetifolium }\end{array}$ & 48 & 37 & 93 & 178 \\
\hline $\begin{array}{l}\text { Cymodocea } \\
\text { serrulata }\end{array}$ & 2 & 5 & 57 & 64 \\
\hline $\begin{array}{l}\text { Thalassodendro } \\
n \text { ciliatum }\end{array}$ & 77 & 79 & 38 & 194 \\
\hline $\begin{array}{l}\text { Halophila } \\
\text { ovalis }\end{array}$ & 2 & 1 & 5 & 8 \\
\hline Total & 173 & 156 & 246 & 575 \\
\hline
\end{tabular}

Kepadatan jenis lamun terendah terdapat pada Stasiun 2. Hal ini diduga karena pada Stasiun 2 terjadi banyak aktivitas manusia di bidang pariwisata seperti snorkeling, aktivitas boat, flying fish. Selain itu kegiatan nelayan dalam menangkap ikan juga diduga dapat mengganggu kelangsungan hidup lamun. Riniatsih (2016) menyatakan kerusakan padang lamun terbesar diakibatkan oleh aktivitas manusia secara langsung.

\subsubsection{Kepadatan Jenis Echinodermata}

Diadema setosum memiliki kepadatan tertinggi pada masing-masing stasiun. Tingginya kepadatan Diadema setosum (Tabel 5) diduga karena Diadema setosum dapat hidup pada semua habitat salah satunya adalah lamun, pernyataan ini didukung oleh Firmandana (2014) menyatakan bahwa Diadema setosum yang dapat ditemukan pada hampir semua daerah mulai dari rataan pasir, padang lamun, rataan karang dan tubir, hingga ke daerah bebatuan. Pada Stasiun 1 Tripneustes gratilla memiliki kepadatan yang sama dengan Diadema setosum. Hal ini diduga karena Tripneustes gratilla memiliki kebiasaan hidup mengelompok, pernyataan ini didukung oleh Budiman et al., (2014) menyatakan bahwa Diadema setosum, Tripneustes gratilla, dan Temnopleurus biasanya hidup mengelompok.
Kepadatan jenis terendah pada Stasiun masingmasing adalah Amphiura sp., Centrostephanus rodgersii, Echinothrix diadema, Mespilia globules, Echinothrix mathei, Pseudoboletia maculates. Hal ini diduga karena jenis tersebut memiliki kebiasan hidup yang menyendiri, pernyataan ini didukung oleh Budiman et al., (2014) yang menyatakan bahwa jenis-jenis Echinodermata, seperti Toxopneustes pileolus, Salmacis bicolor, Echinothrix calamaris, Echinothrix diadema, Mespilia globule, Pseudoboletia maculates cenderung hidup menyendiri.

Tabel 5

Kepadatan Jenis Echinodermata di Pantai Samuh

\begin{tabular}{|c|c|c|c|c|}
\hline \multirow[t]{2}{*}{ Nama Spesies } & \multicolumn{3}{|c|}{ Stasiun (individu/ $\mathrm{m}^{2}$ ) } & \multirow{2}{*}{$\begin{array}{c}\text { Total } \\
\left(\text { ind } / \mathrm{m}^{2} \text { ) }\right.\end{array}$} \\
\hline & $\begin{array}{c}\text { Stasiun } \\
1\end{array}$ & $\begin{array}{c}\text { Stasiun } \\
2\end{array}$ & $\begin{array}{c}\text { Stasiun } \\
3 \\
\end{array}$ & \\
\hline Archaster typicus & - & 0,7 & 0,7 & 1,4 \\
\hline Asterias sp. & - & 0,7 & 1,0 & 1,7 \\
\hline $\begin{array}{l}\text { Protoreaster } \\
\text { nodusus }\end{array}$ & 2,0 & 1,0 & 1,3 & 4,3 \\
\hline Amphiura sp. & 0,3 & 0,3 & 0,7 & 1,3 \\
\hline $\begin{array}{l}\text { Ophiactis } \\
\text { resillens }\end{array}$ & - & 1,0 & 1,7 & 2,7 \\
\hline $\begin{array}{l}\text { Ophiopteris } \\
\text { antipodum }\end{array}$ & - & 0,7 & 0,7 & 1,4 \\
\hline $\begin{array}{l}\text { Centrostephanus } \\
\text { rodgersii }\end{array}$ & 0,3 & - & 0,7 & 1,0 \\
\hline Diadema setosum & 2,3 & 8,7 & 8,0 & 19,0 \\
\hline $\begin{array}{l}\text { Echinothrix } \\
\text { diadema }\end{array}$ & 0,3 & 0,7 & 1,0 & 2,0 \\
\hline $\begin{array}{l}\text { Echinothrix } \\
\text { mathei }\end{array}$ & - & 0,3 & 1,0 & 1,3 \\
\hline $\begin{array}{l}\text { Mespilia } \\
\text { globulus }\end{array}$ & 0,3 & 0,7 & - & 1,0 \\
\hline $\begin{array}{l}\text { Pseudoboletia } \\
\text { maculate }\end{array}$ & - & 0,7 & 0,3 & 1,0 \\
\hline $\begin{array}{l}\text { Tripneustes } \\
\text { gratilla }\end{array}$ & 2,3 & 2 & 0,7 & 5,0 \\
\hline
\end{tabular}

\subsection{Komposisi Jenis}

\subsubsection{Komposisi Jenis Lamun}

Komposisi jenis lamun pada Stasiun 1 dan 2 didominasi oleh lamun jenis Thalassodendron ciliatum. Hal ini diduga karena lamun jenis Thalassodendron ciliatum menyukai habitat dengan kondisi substrat pasir berlumpur. Pada Stasiun 1 dan 2 merupakan lokasi penelitian dengan substrat pasir berlumpur sehingga dapat mendukung kehidupan lamun jenis Thalassodendron ciliatum. Kurnia et al. (2015) menyatakan lamun jenis Thalassodendron ciliatum mempunyai karakteristik hidup di daerah perairan dangkal dan terbuka serta bersubstrat dasar pasir 
berlumpur dan pasir kasar. Komposisi jenis lamun pada Stasiun 3 didominasi oleh lamun jenis Sryngodium isoefolium, hal ini diduga karena Sryngodium isoefolium menyukai perairan yang dangkal dan dekat dengan hamparan terumbu. Kondisi pada Stasiun 3 yaitu terdapat gundukan batu karang. Hal ini sesuai dengan pendapat Tangke (2010) menyatakan bahwa jenis Sryngodium isoefolium dapat ditemukan di daerah intertidal, pada daerah dangkal di hamparan terumbu. Hasil komposisi lamun dari 3 stasiun dapat dilihat pada Tabel 6.

Tabel 6

Komposisi Jenis Lamun

\begin{tabular}{lccc}
\hline \multirow{2}{*}{ Jenis Lamun } & \multicolumn{3}{c}{ Komposisi Jenis Lamun } \\
\cline { 2 - 4 } & $\begin{array}{c}\text { Stasiun 1 } \\
(\%)\end{array}$ & $\begin{array}{c}\text { Stasiun 2 } \\
(\%)\end{array}$ & $\begin{array}{c}\text { Stasiun 3 } \\
(\%)\end{array}$ \\
\hline $\begin{array}{l}\text { Enhalus acoroides } \\
\text { Sryngodium }\end{array}$ & 25,43 & 21,79 & 21,54 \\
$\begin{array}{l}\text { isoefolium } \\
\text { Cymodocea }\end{array}$ & 27,74 & 23,71 & 37,80 \\
$\begin{array}{l}\text { serrulata } \\
\text { Thalassodendron } \\
\text { ciliatum }\end{array}$ & 1,16 & 3,20 & 23,17 \\
Halophila ovalis & 44,50 & 50,64 & 15,44 \\
\hline
\end{tabular}

Tabel 7.

Komposisi Jenis Echinodermata

\begin{tabular}{lccc}
\hline \multirow{2}{*}{$\begin{array}{l}\text { Jenis } \\
\text { Echinodermata }\end{array}$} & \multicolumn{3}{c}{ Komposisi Jenis Echinodermata } \\
\cline { 3 - 5 } & Stasiun 1 & Stasiun 2 & Stasiun 3 \\
\cline { 1 - 1 } Archaster typicus & - & $(\%)$ & $(\%)$ \\
Asterias sp. & - & 3,8 & 3,8 \\
Protoreaster nodusus & 25 & 5,8 & 5,7 \\
Amphiura sp. & 4,2 & 1,9 & 3,5 \\
Ophiactis resillens & - & 5,8 & 9,4 \\
Ophiopteris & - & 3,8 & 3,8 \\
antipodum & & & \\
Centrostephanus & 4,2 & - & 3,8 \\
rodgersii & & & \\
Diadema setosum & 29 & 50 & 45,3 \\
Echinothrix diadema & 4,2 & 3,8 & 5,7 \\
Echinothrix mathei & - & 1,9 & 5,7 \\
Mespilia globulus & 4,2 & 3,8 & - \\
Pseudoboletia & - & 3,8 & 1,9 \\
maculate & & & \\
\hline
\end{tabular}

\subsubsection{Komposisi Jenis Echinodermata.}

Komposisi jenis Echinodermata yang paling mendominasi di ketiga Stasiun yaitu Diadema setosum. Hal ini diduga karena ekosistem lamun merupakan sumber makanan bagi Diadema setosum. Pernyataan ini didukung oleh Sari dan Dahlan (2015) yang menyatakan bahwa Diadema setosum dapat menjadi ancaman padang lamun karena Diadema setosum merupakan salah satu jenis Echinodermata pemakan lamun yang utama. Hasil komposisi Echinodermata dari 3 stasiun dapat dilihat pada Tabel 7.

\subsection{Pola Sebaran}

\subsubsection{Pola Sebaran Lamun}

Tabel 8 menunjukan bahwa seluruh spesies lamun mempunyai pola penyebaran seragam dan mengelompok. Bervariasinya indeks dispersi pada setiap spesies menunjukan tingkat pengelompokan yang berbeda-beda dari tiap-tiap spesies tersebut.

Tabel 8

Pola Sebaran Lamun

\begin{tabular}{lccc}
\hline \multirow{2}{*}{ Nama } & \multicolumn{3}{c}{ Stasiun } \\
\cline { 2 - 4 } & Seragam & Seragam & Kelompok \\
\hline $\begin{array}{l}\text { Enhalus } \\
\text { acoroides }\end{array}$ & Sryngodium \\
$\begin{array}{l}\text { isoefolium } \\
\text { Cymodocea } \\
\text { serrulata }\end{array}$ & Seragam & Seragam & Kelompok \\
$\begin{array}{l}\text { Thalassodendron } \\
\text { ciliatum }\end{array}$ & Kelompok & Kelompok & Seragam \\
Halophila ovalis & Seragam & Seragam & Kelompok \\
\hline
\end{tabular}

Berdasarkan Tabel 8 beberapa jenis lamun mempunyai pola sebaran seragam dan beberapa pola sebaran mengelompok. Pada Stasiun 1 dan 2 kelima jenis lamun memiliki pola sebaran seragam kecuali Thalassodendron ciliatum yang memiliki pola sebaran mengelompok. Hal ini diduga karena Thalassodendron ciliatum memiliki kemampuan beradaptasi dengan baik terhadap tipe substrat pasir berlumpur. Stasiun 1 dan 2 memiliki tipe substrat pasir berlumpur. Kurnia et al. (2015) menyatakan bahwa Thalassodendron ciliatum mampu hidup dalam semua jenis substrat, namun yang paling disukai adalah jenis substrat berlumpur. Sedangkan Thalassodendron ciliatum pada Stasiun 3 didapatkan pola sebaran seragam (Tabel 9). Hal ini dikarenakan tipe substrat pada Stasiun 3 adalah substrat jenis pasir. Hal ini didukung pernyataan Feryatun (2012) menyatakan bahwa substrat menentukan sejauh mana lamun 
tumbuh, jenis substrat yang relatif halus lebih disukai lamun untuk tumbuh dibandingkan tipe substrat yang kasar.

Tabel 9

Pola Sebaran Echinodermata

\begin{tabular}{lclc}
\hline \multirow{2}{*}{ Nama } & \multicolumn{3}{c}{ Stasiun } \\
\cline { 2 - 4 } Diadema setosum & \multicolumn{2}{c}{2} & 3 \\
\cline { 2 - 4 } Amphiura sp. & Seragam & Kelompok & Seragam \\
Archaster typicus & - & Seragam & Seragam \\
Asterias sp. & - & Seragam & Seragam \\
Mespilia globules & Seragam & Seragam & - \\
Tripneuste gratilla & Seragam & Seragam & Seragam \\
Pseudoboletia & - & Seragam & Seragam \\
maculate & & & \\
Protoreaster nodusus & Seragam & Seragam & Seragam \\
Ophiactis resillens & - & Seragam & Seragam \\
Ophiopteris & & Seragam & Seragam \\
antipodum & - & & \\
Centrostephanus & Seragam & - & Seragam \\
rodgersii & & & Seragam \\
Echinothrix diadema & Seragam & Seragam & Seragam \\
Echinothrix mathei & - & Seragam & \\
\hline
\end{tabular}

Berdasarkan perhitungan Indeks Dispersi Morisita pada Stasiun 1, 2, dan 3 menunjukkan pola sebaran seragam dari 12 filum dari Echinodermata (Tabel 9). Hal ini diduga karena adanya mobilisasi sehingga keberadaannya dapat berpindah. Pernyataan ini didukung oleh Laning et al. (2014) menyatakan bahwa Echinodermata dapat hidup, tumbuh, dan menyebar karena memiliki sifat mobilisasi atau perpindahan tempat. Sedangkan Diadema setosum pada Stasiun 2 memiliki pola sebaran mengelompok. Hal ini diduga karena Diadema setosum di temukan dalam jumlah yang lebih banyak dalam cekungan batu karang yang berdiameter $\pm 1 \mathrm{~m}$. Pernyataan ini didukung Sari dan Dahlan (2015) menyatakan bahwa kebanyakan Diadema setosum beraturan hidup pada substrat yang keras, yakni batu-batuan atau terumbu karang dan hanya sebagian kecil yang menghuni substrat pasir dan lumpur, karena pada kondisi demikian kaki tabung sulit untuk mendapatkan tempat melekat.

\subsection{Asosiasi Echinodermata dengan Lamun}

Hasil analisis menunjukan ditemukan asosiasi positif tertinggi terdapat pada Stasiun 3 sebanyak 24 pasang. Asosiasi negatif tertinggi terdapat pada
Stasiun 2 sebanyak 24 pasang, sedangkan asosiasi tidak berhubungan terdapat pada Stasiun 1 sebanyak 40 pasang (Tabel 10).

Hasil perhitungan Indeks Asosiasi didapatkan asosiasi positif, asosiasi negatif, dan asosiasi tidak berhubungan. Asosiasi positif antara Echinodermata dan Lamun tertinggi didapatkan pada Stasiun 3 dengan jumlah 24 pasang, hubungan antara keduanya juga tergolong kuat berdasarkan Indeks Jaccard.

Lamun dan kepadatan Echinodermata pada Stasiun 3 memiliki nilai tertinggi dibandingkan dengan stasiun yang lain, sehingga terjadinya peluang saling menguntungkan antara keduannya. Hal ini didukung oleh pernyataan Riniatsih (2016), yang menyatakan bahwa salah satu peranan lamun di perairan adalah sebagai habitat biota. Salah satu biota yang hidup di daerah padang lamun yaitu adalah Echinodermata, secara ekologis Echinodermata berperan penting pada tingkat kesuburan substrat dasar perairan di sekitarnya karena secara tidak langsung Echinodermata merupakan biota bentik pemakan deposit (deposit feeder). Echinodermata mencerna sejumlah besar sedimen, yang memungkinkan untuk terjadinya oksigenisasi lapisan atas sedimen, proses ini mencegah terjadinya penumpukan pembusukan bahan-bahan organik dan membantu mengontrol populasi hama dan bakteri-bakteri patogen tertentu (Wulandari et al., 2012).

Tabel 10

Asosiasi Echinodermata dengan Lamun

\begin{tabular}{cclccc}
\hline \multirow{2}{*}{ Asosiasi } & Indeks & \multirow{2}{*}{ Keterangan } & \multicolumn{3}{c}{ Stasiun } \\
\cline { 4 - 6 } & Asosiasi & & 1 & 2 & 3 \\
\hline \multirow{4}{*}{ Positif } & $1.00-0.75$ & Sangat Tinggi & 0 & 0 & 0 \\
& $0.74-0.49$ & Tinggi & 0 & 12 & 24 \\
& $0.48-0.23$ & Rendah & 10 & 8 & 0 \\
& $<0.22$ & Sangat Rendah & 0 & 0 & 0 \\
\hline Sub total & & & 10 & 20 & 24 \\
\hline \multirow{4}{*}{ Negatif } & $1.00-0.75$ & Sangat Tinggi & 0 & 0 & 0 \\
& $0.74-0.49$ & Tinggi & 15 & 24 & 22 \\
& $0.48-0.23$ & Rendah & 0 & 0 & 0 \\
Sub total & $<0.22$ & Sangat Rendah & 0 & 0 & 0 \\
\hline \multirow{4}{*}{ Tidak } & & & 15 & 24 & 22 \\
Jelas & $0.74-00-0.75$ & Sangat Tinggi & 0 & 1 & 0 \\
& $0.48-0.23$ & Tinggi & 6 & 14 & 6 \\
\hline Sub total & $<0.22$ & Rendah & 4 & 1 & 8 \\
\hline Total & & & 30 & 5 & 5 \\
\hline
\end{tabular}


Asosiasi negatif antara Echinodermata dan Lamun tertinggi terdapat pada Stasiun 2 dengan jumlah 24 pasang. Berdasarkan Indeks Jaccard asosiasi negatif pada Stasiun 2 memiliki hubungan yang kuat. Pada Stasiun 2 kepadatan Echinodermata lebih tinggi daripada kepadatan lamun. Tingginya kepadatan Echinodermata dapat menciptakan peluang negatif (peluang merugikan) terhadap lamun. Salah satu jenis Echinodermata yang paling mendominasi pada Stasiun 2 adalah Diadema setosum yang merupakan hama pada lamun. Menurut Sari dan Dahlan (2015) menyatakan bahwa Diadema setosum dapat menjadi ancaman pada padang lamun karena Diadema setosum merupakan salah satu jenis Echinodermata pemakan lamun yang utama.

Asosiasi tidak berhubungan merupakan asosiasi yang tidak saling mempengaruhi satu sama lain. Nilai asosiasi tidak berhubungan tertinggi terdapat pada Stasiun 1 dengan jumlah 40 pasang. pada Stasiun 1 kepadatan Echinodermata lebih rendah daripada kepadatan lamun. Komposisi jenis Echinodermata yang ditemukan pada Stasiun 1 hanya 7 jenis, nilai ini tergolong sedikit jika dibandingkan dengan Stasiun 2 dan 3. Hal ini diduga sebagai pemicu terjadinya asosiasi tidak berhubungan karena semakin sedikit jenis dan kepadatan Echinodermata pengaruh terhadap lamun juga semakin sedikit. Mengingat peran Echinodermata terhadap lamun sebagai detritus (asosiasi positif) dan sebagai pemakan lamun utama (asosiasi negatif), sehingga sedikitnya Echinodermata yang ditemukan pada Stasiun 1 memiliki pengaruh hanya sebagai penyeimbang antara asosiasi positif dan asosiasi negatif. Hal ini didukung oleh pernyataan Mayasari et al. (2012), yang menyatakan bahwa asosiasi tidak berhubungan terjadi apabila ada atau tidaknya jenis biota namun mereka tidak saling mempengaruhi satu sama lain, asosiasi tidak ada hubungan dijadikan sebagai penyeimbang kekuatan positif dan kekuatan negatif.

\subsection{Parameter Kualitas Air}

Berdasarkan pengukuran parameter suhu, $\mathrm{DO}, \mathrm{pH}$, dan salinitas (Gambar 3) didapatkan hasil bahwa parameter tersebut dapat ditolerir oleh kehidupan organisme perairan serta lamun. Hal ini didukung pernyataan Hartati et al. (2012) dalam penelitiannya menyatakan bahwa semua parameter kualitas air yang memenuhi ambang batas yang ditetapkan masih dapat mentoleransi untuk keberlangsungan hidup.
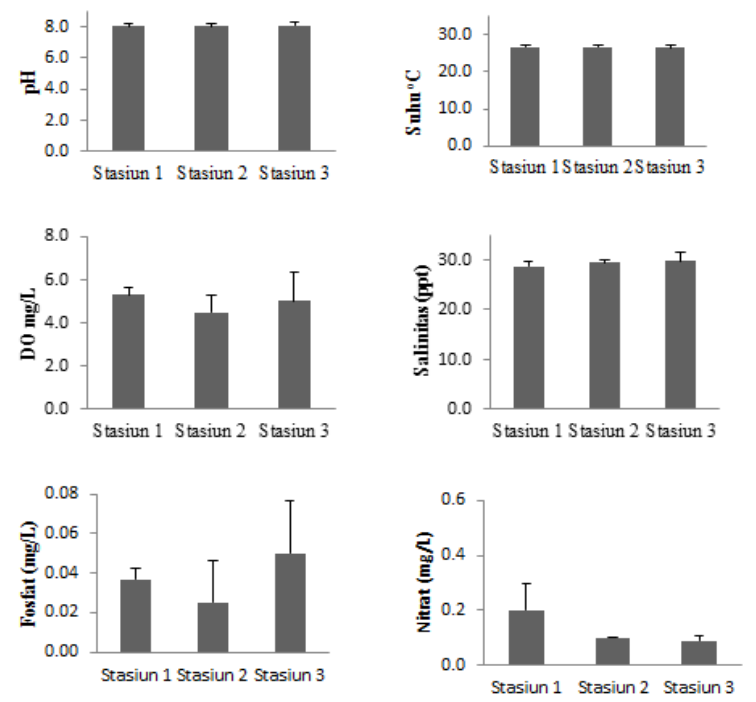

Gambar 3. Parameter Kualitas Air

\section{Simpulan}

Kepadatan Echinodermata tertinggi adalah Diadema setosum pada masing-masing stasiun, sedangkan kepadatan terendah adalah jenis Amphiura sp., Centrostephanus rodgersii, Echinothrix diadema, Mespilia globules, Echinothrix mathei, Pseudoboletia maculates. Dengan komposisi jenis Echinodermata yang ditemukan sebanyak 13 spesies yaitu Diadema setosum, Amphiura sp, Archaster typicus, Asterias sp., Mespilia globulus, Tripneustes gratilla, Pseudoboletia maculata, Protoreaster nodusus, Ophiactis resillens, Ophiopteris antipodum, Centrostephanus rodgersii, Echinothrix dan Echinothrix mathei, dan memiliki pola sebaran seragam dan mengelompok. Hasil analisis asosiasi antara lamun dengan Echinodermata di perairan Pantai Samuh, Nusa Dua, Bali ditemukan adanya asosisasi positif, asosiasi negatif dan asosiasi tidak berhubungan. Asosiasi positif tertinggi pada terdapat pada Stasiun 3 sebanyak 24 pasang. Asosiasi negatif tertinggi terdapat pada Stasiun 2 sebanyak 24 pasang, sedangkan asosiasi tidak ada hubungan terdapat pada Stasiun 1 sebanyak 40 pasang.

\section{Ucapan terimakasih}

Terima kasih kepada pihak-pihak yang selalu memberikan motivasi dan membantu dalam penyelesaian penelitian ini.

\section{Daftar Pustaka}

Bass, J. I. F., Diallo, A., Nelson, J., Soto, J. M., Myers, C. L., \& Walhout, A. J. (2013). Using networks to measure 
similarity between genes: association index selection. Nature methods, 10(12), 1169-1176.

Brower, J. E., Zar, J. H., \& von Ende, C. (1998). Field and laboratory methods for general ecology. Illinois, USA: Wm. C. Brown Company Publishers.

Budiman, C. C., Maabuat, P. V., Langoy, M. L., \& Katili, D. Y. (2014). Keanekaragaman Echinodermata di Pantai Basaan Satu Kecamatan Ratatotok Sulawesi Utara. Jurnal Mipa Unsrat Online, 3(4), 97-101.

Dwindaru, B. (2012). Variasi spasial komunitas lamun dan keberhasilan transplantasi lamun di Pulau Pramuka dan Kelapa Dua, Kepulauan Seribu, Provinsi. DKI Jakarta. Skripsi. Bogor: Departemen Manajemen Sumberdaya Perairan, Fakultas Perikanan Dan Ilmu Kelautan, Institut Pertanian Bogor.

Firmandana, T. C. (2014). Kelimpahan Bulu Babi (Sea Urchin) Pada Ekosistem Karang Dan Lamun Di Perairan Pantai Sundak, Yogyakarta. Management of Aquatic Resources Journal, 3(4), 41-50.

Hidayanti, (2016). Tempat wisata Pantai Segara Samuh Nusa Dua Bali. (www.longtripmania.org). [diakses 15 Desember 2016].

Hadi, A., Hartati, R., \& Widianingsih, W. (2011). Fauna Echinodermata di Indonoor Wreck, Pulau Kemujan, Kepulauan Karimunjawa. ILMU KELAUTAN: Indonesian Journal of Marine Sciences, 16(4), 236-242.

Hartati, R., Djunaedi, A., Hariyadi, H., \& Mujiyanto, M. (2012). Struktur komunitas padang lamun di perairan Pulau Kumbang, Kepulauan. ILMU KELAUTAN: Indonesian Journal of Marine Sciences, 17(4), 217-225.

Kurnia, M., Pharmawati, M., \& Yusup, D. S. (2015) Jenisjenis lamun di pantai Lembongan, Nusa Lembongan dan analisisnya dengan PCR ruas RbCL. Simbiosis Journal Of Biological Sciences, 3(2), 330-333.
Kurniawan, A., Undaharta, N. K. E., \& Pendit, I. M. R. (2008). Association of dominated tree species in lowland tropical forest of Tangkoko Nature Reserve, Bitung, North Sulawesi. Biodiversitas Journal of Biological Diversity, 9(3), 199-203.

Laharjana, K. A. K. (2016). Asosiasi moluska benthik dengan lamun di perairan Pulau Serangan Bali. Skripsi. Denpasar, Indonesia: Program Studi Ilmu Kelautan, Fakultas Kelautan dan Perikanan, Universitas Udayana.

Mayasari, A., Kinho, J., \& Suryawan, A. (2012). Asosiasi eboni (Diospyros spp.) dengan jenis-jenis pohon dominan di Cagar Alam Tangkoko Sulawesi Utara. Info Balai Penelitian Kehutanan Manado, 2(1), 55-72.

Rasyid, F. (2001). Sebaran dan Asosiasi Makroinfauna pada Ekosistem Padang Lamun di Perairan Teluk Humn, Teluk Lampung, Lampung Selatan. Skripsi. Bogor, Indonesia: Program Studi Ilmu Kelautan Fakultas Perikanan dan Ilmu Kelautan Institut Pertanian Bogor.

Riniatsih, I. (2016). Distribusi jenis lamun dihubungkan dengan sebaran nutrient perairan di padang lamun Teluk Awur Jepara. Jurnal Kelautan Tropis, 19(2), 101107.

Sari, A., \& Dahlan, D. (2015). Komposisi jenis dan tutupan lamun di perairan teluk yos sudarso Kota Jayapura. The Journal of Fisheries Development, 2(3), 1-8.

Tangke, U. (2010). Ekosistem padang lamun (manfaat, fungsi dan rehabilitasi). Agrikan: Jurnal Ilmiah Agribisnis dan Perikanan, 3(1), 9-29.

Wulandari, N., Krisanti, M., \& Elfidasari, D. (2012). Keragaman teripang asal Pulau Pramuka, Kepulauan Seribu Teluk Jakarta. Unnes Journal of Life Science, 1(2), 133-139.

(C) 2018 by the authors; licensee Udayana University, Indonesia. This article is an open access article distributed under the terms and conditions of the Creative Commons Attribution license (http://creativecommons.org/licenses/by/3.0/). 